\title{
||||||||||||||||
}

\section{特集 不完全な知識の下での推論}

\section{仮説推論 ${ }^{\dagger}$}

\section{石塚 満*}

\section{1. はじめに}

一般的に述べると仮説推論は、真か偽か不明な 事柄をとりあえず真と考えて(仮説を立てて)推論 を進め、矛盾なくうまく問題が解決できれば(ゴー ルに到達すれば）立てた仮説は正しかったと考え るという形式の推論である。仮説という真か偽か 不明で他の知識と矛盾する可能性を有する不完全 な知識も扱うということで、知識ベースの能力の 幅を広げることができる ${ }^{[1,2]}$ 。（従来の知識ベース は常に成り立つ知識を集めて、演繹的推論により 答を求める構造となっている。）しかし、仮説は否 定される可能性のある知識 (defeasible knowledge)であり、知識ベースが不完全な知識である このような仮説を含むと非単調推論(nonmonotonic reasoning) が必要になり、低い推論 速度が大きな問題になる。

本稿では筆者らの研究を中心として、仮説推論 の原理、応用、高速推論メカニズムについて紹介 し、最後にファジィ推論との差異について触れる ことにしたい。

\section{2. 論理に基づく仮説推論}

形式が整つている論理は知識表現と推論の基盤 として重要な役割を果す。仮説推論にも幾つかの バリエーションがあるが、ここでは論理に基づく 仮説推論 ${ }^{[2-5]}$ について紹介する。

$\dagger$ Hypothetical Reasoning

* Mitsuru ISHIZUKA

東京大学 生産技術研究所

Institute of Industrial Science, Univ. of Tokyo
この仮説推論は図 1 に示すように、知識ベース を完全な知識(対象世界で常に成り立ち矛盾の可 能性のない知識)の集合 $\mathrm{F}$ と、仮説 (hypothesis) の知識(対象世界で常に成り立つとは限らず矛盾 の可能性をもつ知識)の集合 $\mathrm{H}$ とに分ける。 $\mathrm{H}$ の 部分集合を $h$ 、すなわち $h \subseteq H$ とする。

基本的な推論動作は次のとおりである。ゴール Gが与えられたとき、まず F から G が演繹的に証 明できるか確かめる。F からだけでは証明できな いとき、次の条件を満たす hを求める。

$$
\left\{\begin{aligned}
& \mathrm{F} \cup \mathrm{h} \vdash \mathrm{G}(\mathrm{F} \text { と h から } \mathrm{G} \text { が証明できる； } \\
&\text { トは演繹的証明を示す論理記号 }) \\
& \mathrm{F} \cup \mathrm{h} \text { は無矛盾 }
\end{aligned}\right.
$$

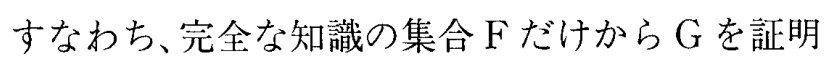
できればそれでよいが、Fからだけでは $\mathrm{G}$ を証明 できないとき、仮説の集合 $\mathrm{H}$ の中から無矛盾な部 分集合 $\mathrm{h}$ を切り出し、 $\mathrm{F}$ と合わせて $\mathrm{G}$ を証明する ようにする。多くの場合、hは最小性(または非て

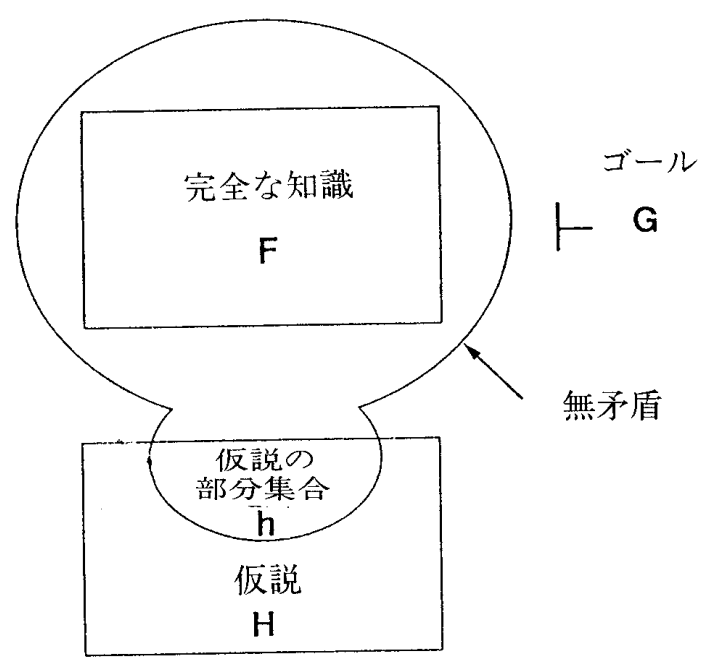

図 1 論理に基づく仮説推論の基本構造 
長性）、すなわち hの部分集合 h'が上記の条件を 満たさないことも要請される。

我々の頭脳の中にも互いに矛盾を生ずる可能性 のあるような不完全な知識が多数あるが、与えら れた一つの問題に対する解を求劣ときは、あ る無矛盾な知識の範囲を切り出してきて問題に対 処する。上記の仮説推論はこのような人間の思考 法に対応しているといえる。

通常の演繹推論では、知識ベースからゴール $\mathrm{G}$ が証明できるとき成功 ( $G$ は真)、証明できないと き不成功 $(\mathrm{G}$ は偽) となり、 $\mathrm{G}$ が変数を含む場合、 成功のときには変数へ代入 (束縛) された值も解と して返される。これに対し、上記の仮説推論では Gは証明することが条件であり、この証明に必要 な無矛盾な仮説 h を生成する。すなわち、演繹推 論を逆向きに利用して解を求める構造になってい る。

完全な知識は不完全な知識の一種とも考えるこ とができ、両者を区別せずすべての知識を仮説と して知識べースを構成することも原理的には可能 である。しかし、これでは推論の効率が悪くなる。 すなわち、仮説は矛盾の可能性があるので、使用 時には無矛盾性チェックの計算が必要であり、時 間がかかる。常に正しく矛盾となる可能性がない 知識を完全な知識として分離し、無矛盾性チェッ クを省略できるようにすることは、実用的な推論 速度を達成するために不可欠である。また多くの 場合、可能な仮説はあらかじめ記述しておくとい う形式を採るが、これも考虑する仮説の範囲を限 定し実用的な推論速度とするために必要である。 ゴールの証明のために不足している仮説を何もな いところから生成することも可能であり、この場 合は発想 (abduction)*を実現する推論となる。

知識ベースが不完全な知識を含むと推論が非単 調となる。仮説は不完全な知識の一種であり後に 否定される可能性をもつので、仮説推論も一つの 非単調推論系である。不完全な知識に関係する非

(脚注)* $\mathrm{A} \rightarrow \mathrm{B}$ と A から $\mathrm{B}$ を帰結として推論するのが演繹 (deduction)である。これに対し、発想は $\mathrm{A} \rightarrow \mathrm{B}$ と $\mathrm{B}$ からAであろうと推論する形の推論である。
単調推論系には、ディフォルト論理、様相論理に よる非単調論理、自己認識論理、サーカムスクリ プション(極小限定)などもある。これらの非単調 推論系間の関係も、次第に明らかになってきてい $ろ^{[1]}$ 。非単調推論系の中で、ここでの仮説推論は 困 1 による説明から理解されると思うが、最もシ ンプルな形式のものである。最もシンプルな形式 でありながら以下に例示するように、他の非単調 推論系にはない、実用的問題へ直接的に適用でき る枠組みとなっている点が大きな特徴である。

\section{3. 診断型問題之設計型問題への適用}

仮説推論システムの実用性を示すために、例を 挙げて診断型問題と設計型問題への適用法を示す。

診断問題は観測事象 (故障の症状)を説明するの に必要な仮説(故障の原因)を生成する問題ととら えられ、認識問題も同じ構造としてとらえられる。 設計問題では与えられた仕様を満たすのに必要な 仮説(設計要素、部品)の組合せを生成する問題と してとらえられ、診断型問題と同様に仮説推論を 適用できるが、解の探索空間が非常に大きくなる ので効率的な推論機構が必要となる。

\section{（3－1） ディジタル回路の故障診断}

仮説推論の診断問題への適用の基本的な考え方 は次のとおりである。故障の可能性のない(常に正 しい)システム要素を完全な知識 $F$ として記述し、 故障の可能性を仮説 $\mathrm{H}$ として記述する。起り得な い仮説の組合せの状況を矛盾として記述する(F の一種である制約知識となる)。そして、故障の症 状の観測をゴール Gとして与える。論理に基づく 仮説推論の場合、以上のいずれの記述も論理式と して与える(推論の効率化のためには論理式をホ ーン節に制限した方がよい)。

Prologの推論機能を利用して仮説推論システ ムを実現し、ディジタル回路の故障診断へ適用し た動作例を示しているのが図 2 である ${ }^{[6,7]}$ 。この 場合、ゲート間の結線は故障しないとしているの で、完全な知識 $F$ として記述している。各ゲート 
は正常 (ok)か、出力が 1 に縮退する stuckon、出 力が 0 に縮退する stuckoffの故障の可能性があ るので、これらを仮説として記述する。罒 2 では、 たとえば alゲートが正常 (ok)という仮説は hyp $(\operatorname{stat}(\mathrm{al}, \mathrm{ok}))$ 。ように標記されている。あるゲ 一トは $\mathrm{ok}$ 、stuckon、stuckoff のいずれかであ ク、これらの状態を同時にとることはないので、 同時に生じるのは矛盾であると定義する。
図 2 の下部はシステムの動作を示している。この 回路は入力が 3 本、出力が 2 本あるが、最初に次 のような観測がゴールとしてシステムに与えられ る。

$\left\{\begin{array}{lll}\text { 入力が } 0 、 & 0 、 & 0 \text { のとき、出力が } 0 、 \\ \text { 入力が } 0 、 & 1 、 & 0 \text { のとき、出力が } 0 、 0 \\ \text { 入力が } 1 、 & 0 、 0 \text { のとき、出力が } 0 、 0\end{array}\right.$

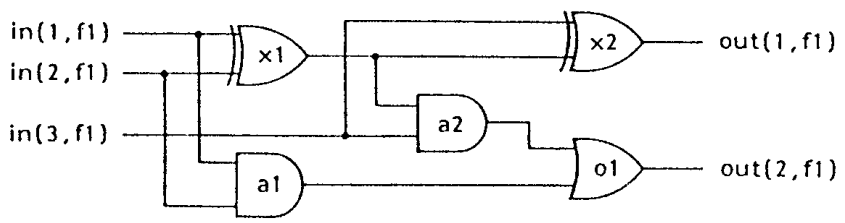

Digital circuit (full adder, name: f1)

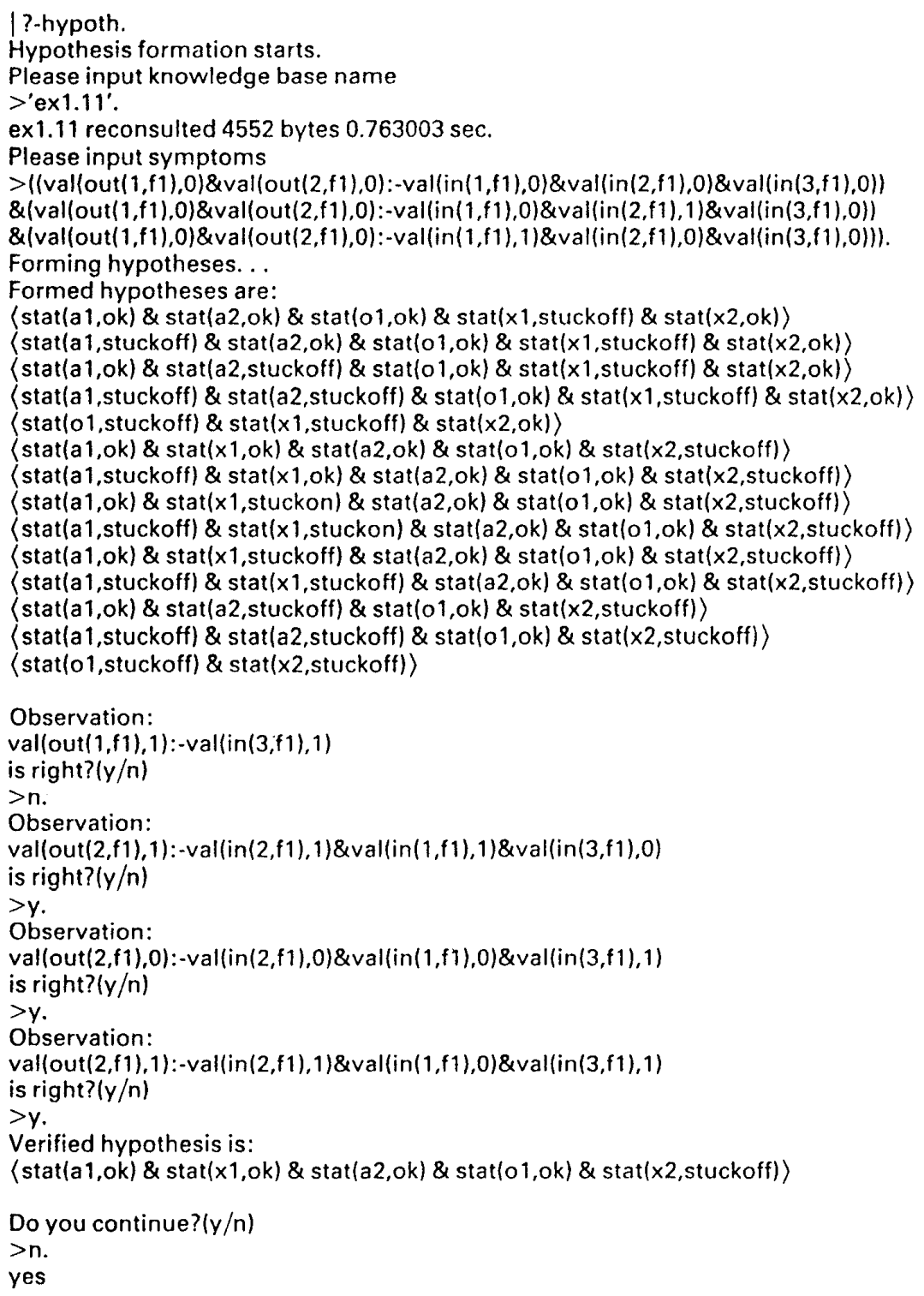

図 2 仮説推論によるデイジタル回路の故障診断 (val (out $(1, \mathrm{f} 1), 0)$ は out $(1, \mathrm{f} 1)$ ノード出力值が0を表し、stat $)$

観測

仮説形成

第 1 ステップで形成 される14の仮説

仮説選定のための

質問応答 
例えばval (out $(1, f 1), 0)$ は 1 番目の出力 out $(1$, f 1)の值が0であることを表している。この観測 事象は正常の動作ではない故障の症状を表してお り、すべてのゲートを正常としたのでは知識べー スから演繹的に証明できない。そこで、仮説推論 機構はゲートの故障の仮説を導入し、観測事象の 証明を成功させようと試みる。

この場合の仮説推論機構は、最初に可能な解仮 説の多重故障も含むすべての組合せを推論するよ うになっている。その結果、与えた観測事象だけ では故障の原因を一意に絞り込むことはできず、 図 2 の中段のように 14 種の仮説の組合せが得ら れる。

仮説推論は矛盾に関する制約を基礎にして動作 するなめ、単に複数の可能な解を生成するので終 わるだけでなく、解を一意に絞り込む追加の質問 を自動的に生成する質問一応答機構を実現できる。 図 2 の下段では、次のような質問一応答が行われ ている。

$$
\left\{\begin{array}{c}
\text { 入力が } 1 \text { のとき、出力 } 1 \text { は } 1 \text { か? 応答 : no } \\
\text { 入力が } 1 、 1 、 0 \text { のとき、出力 } 2 \text { は } 1 \text { か? } \\
\text { 入力が } 0 、 0 、 1 \text { 応答 : yes } \\
\text { 入力が } 0 、 1 、 1 \text { のとき、出力 } 2 \text { は } 0 \text { か? } \\
\text { 応答 : yes } \\
\text { 出? } \\
\text { 応 }: y e s
\end{array}\right.
$$

この結果、解は一意に決まり、次のようになって いる。

$$
\text { x } 2 \text { ゲートが stuckoff }
$$

故障診断の場合は、故障箇所の同定ができない ときに追加の入力に対する出力から故障の範囲を 限定していくことを行うが、これを模擬した動作 が実現されている。質問は複数個生成させた可能

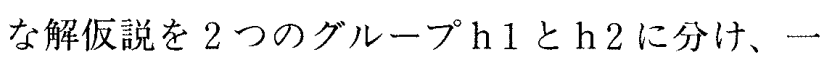
方のグループの仮説から証明でき、他方のグルー プの仮説から証明できないような入力一出力対を 見い出す。そして、yes か no かによって一方のグ ループを残し、他方のグループを菓却するように する。すなわち
$\mathrm{F} \cup \mathrm{h} 1 \vdash \mathrm{G}_{1}$

$\mathrm{F} \cup \mathrm{h} 2 \nless \mathrm{G}_{2} \quad($ は左辺から右辺が証明できな いことを表す)

となるような $\mathrm{G}_{1}$ を見い出し、答えが yes のとき h 1、noのとき h 2 を残して、残りが 1 組の仮説と なるまで続けるようにする。このようにして、解 の絞り込みに効果がある質問のみを生成すること ができる。最も少ない質問回数で一意の解に到達 するようにするために、均等なグループ分け（７個 と 7 個の仮説の組)に対して上記の関係となるよ うな入力一出力対を見い出す必要があるが、これ を行うのは非常に時間がかかる。四2の例では、 3 個と 11 個の仮説の組といったように、とにかく 2 グループの一方の仮説の組を残し、他方を呆却 寸るのに有効な質問を生成している。

症状と原因を結び付ける(ヒューリスティック な)関係をルールで記述する形式のエキスパート システムと比較し、このような仮説推論によるシ ステムは、対象システムの構成要素を常に正しい ものと故障の可能性のあるものとに分けてシステ マティックに記述するだけであり、知識獲得の問 題は大幅に転減される。この記述された知識はシ ステムの機能を構造的に表したものであり、症状 と原因を表層的に結び付ける知識に対して深い知 識に相当し、深い知識に基づく診断が実現される。 このような形態は一般にモデルに基づく診断 (model-based diagnosis) と呼ばれ、その基本原 理として仮説推論は重要な位置を占めている。大 きな課題は推論の筋道を陽にガイドする役割を果 たすヒューリスティックな知識に依存しないため、 推論速度が十分でないことである。この高速化手 法については後述する。

\section{(3-2) 回路ブロックの設計システムの例}

設計は一種の創造活動であり、創造活動の支援 は今後の知識システムの適用領域としてますます 重要となる。設計問題は一般に、与えられた仕様 を満たす部品の組合せ法を制約の範囲内で見い出 
すことと定式化でき、仮説推論の枠組みはこのよ うな設計問題に対しても有効である。

仮説推論の設計への適用の一般的な考之方は、 特定の部位で使用する可能性のある部品と部品の 間の接続法を仮説 $\mathrm{H}$ として記述しておく。部品の 機能や数式、論理式の変形知識のように、常に正 しく矛盾を引き起こすことのない知識は完全な知 識 Fとして記述する。そして、設計の仕様をゴー ル $\mathrm{G}$ として与えると、仕様を満たす部品と接続法 の組合せが hとして求まることになる。

以下に回路ブロック設計への適用法の例 ${ }^{[8]}$ を示 す。設計の部品となるのは図 3 に示すような機能 ブロックである。設計の場合は解の探索空間が膨 大となるので、論理に基づく仮説推論の Prolog による単純な実装法のように深さ優先の縦型推論 では遅く、何らかの効率的推論制御機構を導入し なければ実用的にはならない。

設計問題では、仕様を満なす全ての設計例を求 めることよりも、多くの場合、仕様を満たすもの の中でより良いものを早く見い出すことが要求さ れる。そして設計の際に与えられる制約条件には 種々のものがあるが、必ず満たさなければならな
い制約から、満たすことが望ましいという制約ま で、その重要度は様々である。そこで、制約条件 の重要度に応じて重みを設定する。そして、推論 の効率化の一つの方法は、推論の過程で全ての制 約を満たすような解に行きつかなかった場合に、 重みの低い制約を満たすことは諦めてこの制約条 件を取り除き(緩和し)、この制約によって止まっ ていな推論の枝を延ばしていく。最初に厳しい制 約から出発し、徐々に制約を緩めていくことによ ク、重要度が高い最も多くの制約を満たす解を最 初に見い出すことができる。

詳細は省略するが、困 4 (a) は設計するカウン 夕の動作仕様であり、(b)は制約である。制約はた とえば、総ブロック数については 3 個以下が重み 10 で、使用する加算器 (Adder) の個数について は0 個が重み 9 というように与えられている。こ の場合には回路の出力ポートから回路の組み立て を行うように推論が進行し、結果として図 5 のよ うなカウンタが生成される。ここでは重み付き制 約の逐次的緩和という方法を採用することによっ てある程度の効率化を図っているが、更に本質的 な高速化メカニズムが必要である。

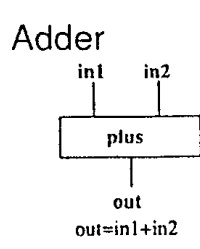

Multiplier

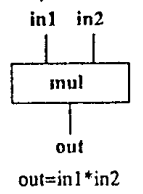

Incrementer

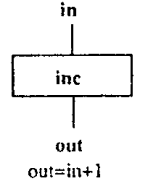

Multiplexer

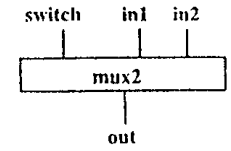

out $=$
iff (switch, in 1, in2)
Subtracter

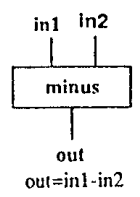

Divider

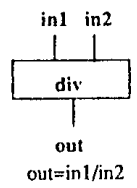

Decrementer

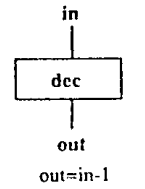

Register

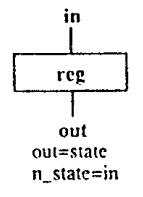

(equ (out $(1, \mathrm{f1})$, state):equ (state $(1, x)$ state $)) \&$

equ (n_state $(1, x)$, iff $(\mathrm{ctrl}$, in, state +1$))$ :equ (in $(1, f 1)$, ctrl) \& equ (in $(2, f 1)$, in) \& equ (state $(1, x)$, state))).

(a)
7 Output Equation

State Transition

図 3 設計の部品となる機能ブロック

$\begin{array}{ll}\text { constraint }(10, \text { ?dev }=<3) . & \text { Total No. of Blocks } \\ \text { constraint }(9, \text { ?plus }=<0) . & \text { No. of Adders } \\ \text { constraint }(5, \text { ?inc }=<1) . & \text { No. of Incrementers } \\ \text { constraint }(5, \text { ?mux2 }=<1) . & \text { No. of Multipliers } \\ \text { constraint }(5, \text { ?reg }=<1) . & \text { No. of Registers }\end{array}$

(b)

図 4 (a) カウンタの動作仕様と (b) 重み付き制約 


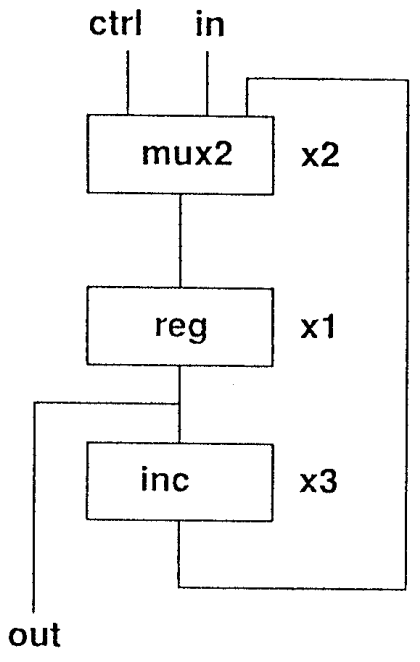

图 5 設計されたカウンタ

\section{4. 仮説推論の高速化}

仮説推論は実用的にも有用な枠組みであるが、 最大の課題は低い推論速度の克服である。実は仮 説推論を始妨るる非単調推論の計算複雑度は $\mathrm{NP}$ 一完全、あるいは NP－困難であると証明され

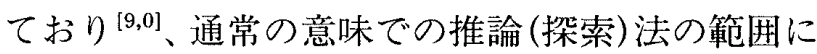
留まっていたのでは、最悪值評価で問題規模の指 数オーダ以下となる推論時間は達成できない。宣 言的表現の論理に基づく仮説推論に関しては、制 約充足問題 (Constraint Satisfaction Problem: $\mathrm{CSP})$ に等価変換でき、この CSP の計算複雑度も $\mathrm{NP}$ 一完全となっている。

ここでは制約充足の立場での問題の構造を利用 した高速化手法と、指数オーダとなる推論時間の 壁を克服する一つの手法について述べようと思う。 広く利用されており高速化に際しての重要な方法 にATMS(Assumption-based Truth Maintenance System)がある[11]。ATMS はデー夕を支持 する無矛盾で非冗長な多重環境 (複数の仮説の組) を、仮説の組の束（lattice）構造に基づいて効率的 に計算し、保持する。ここではこれ以上ATMSに ついて説明はしないが、次の推論パスネットワー クによる高速仮説推論法の仮説合成フェーズは、 このATMS と同様なメカニズムとなっている。

\section{(4-1) 推論パスネットワークによる仮説推論法}

ホーン節論理に基づく仮説推論は Prolog の推 論機構を利用すると比較的容易に実現できるが、 推論速度が遅く実用的でない。推論速度を遅くす る大きな要因はバックトラックであり、通常の証: 明の失敗によるバックトラックに加えて、仮説推 論では組み合わされる仮説間の矛盾によってもバ ックトラックが発生することにより、一層大きな 問題となる。推論パスネットワークによる高速仮 説推論法 ${ }^{[2]}$ は、非効率なバックトラックを回避 し、かつ計算コストが高い仮説合成の回数を最小 にすることを特徴とする手法である。推論パスネ ットワーク形成フェーズと、このネットワークに 沿う前向き推論の仮説合成フェーズとから成る。 推論パスネットワークはゴール指向の後向き推論 によりゴールの証明に関与する知識のみを抽出し てネットワーク化し、かつこれをコンパイルして 仮説合成の回数を最小にする役割を果たす。推論 パスネットワークの形成は命題ホーン節に対する 線形時間の充足性判定アルゴリズムに基づいてお り、非常に効率的である。

図 6 の仮説を含む知識ベースで、ゴールとして $\{a ， b\}$ が与えられたときを例にして概要を説明 する。ゴールから出発する後向き推論により、ま ず図 7 の初期推論パスネットワークを形成する。 図 7 で $f_{1} 、 f_{2}$ は完全知識のファクトとして定義さ れているので真であり、これらを OR 枝としても つノードj、c、oは常に真となるので、それらの 子ノードにつながる仮説は考慮する必要がなくな

完全知識

\begin{tabular}{|c|c|c|}
\hline 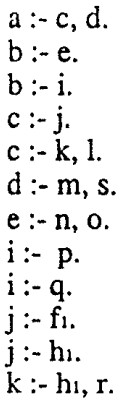 & $\begin{array}{l}1:-\mathrm{r}, \mathrm{h}_{2} . \\
\mathrm{m}:-\mathrm{h}_{2}, \mathrm{~h}_{3} . \\
\mathrm{n}:-\mathrm{h}_{3}, \mathrm{s.} \\
\mathrm{o}:-\mathrm{f}_{2 .} \\
\mathrm{o}:-\mathrm{h}_{4 .} \\
\mathrm{p}:-\mathrm{h}_{4}, \mathrm{~h}_{\mathrm{s}} \\
\mathrm{q}:-\mathrm{t}, \mathrm{u} . \\
\mathrm{r}:-\mathrm{h}_{8 .} \\
\mathrm{r}:-\mathrm{h}_{9} . \\
\mathrm{s}:-\mathrm{h}_{10} . \\
\mathrm{s}:-\mathrm{h}_{11} . \\
\mathrm{t}:-\mathrm{h}_{12}, \mathrm{~h}_{13} .\end{array}$ & $\begin{array}{l}\text { inc :- } h_{1}, h_{9} . \\
\text { inc :- } h_{2}, h_{11} \\
\text { inc :- } h_{11}, h_{13} .\end{array}$ \\
\hline
\end{tabular}

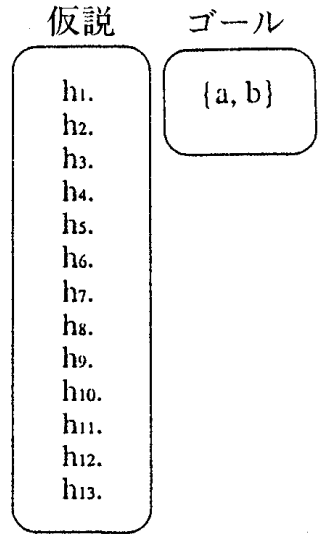

図 6 仮説を含む知識ベースと推論のゴールの例 
る。またノード $u$ は支持仮説が存在しないため、 この知識ベースの状沉では真になることはない。 それを $\mathrm{AND}$ 枝としてもつqは真になることは ないので、その子ノードにつながる仮説も考虑す

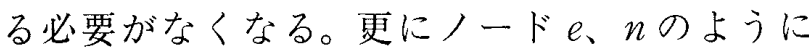
AND、OR 枝でなく連結関係となるノードは1ノ 一ドにマージすることができる。このようにして 困８に示寸ようなコンパイルした推論パスネット ワークを形成することができる。

次の仮説合成フェーズでは図 8 に示すように、 この推論パスネットワークに沿ってボトムアップ に各ノードを支持する仮説を合成する。矛盾とな る仮説の組、他に包摂される冗長な仮説の組をチ エックし、これらを排除する。このチェックは ATMS と同様に、仮説の組をビットベクトルで表 し、ビットベクトル間の演算で行うようにして効 率化を図っている。ゴールのノードまでボトムア ップに合成されてきた無矛盾な仮説の組が解仮説 として求まり、この例では $\left\{h_{2} 、 h_{3}, h_{10}\right\}$ が求ま っている。

困 9 は推論パスネットワークによる仮説推論シ ステムの速度を、Prologによる仮説推論システム と比較しな例であり、1,000 倍以上の速度の向上

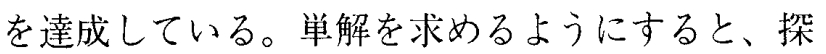

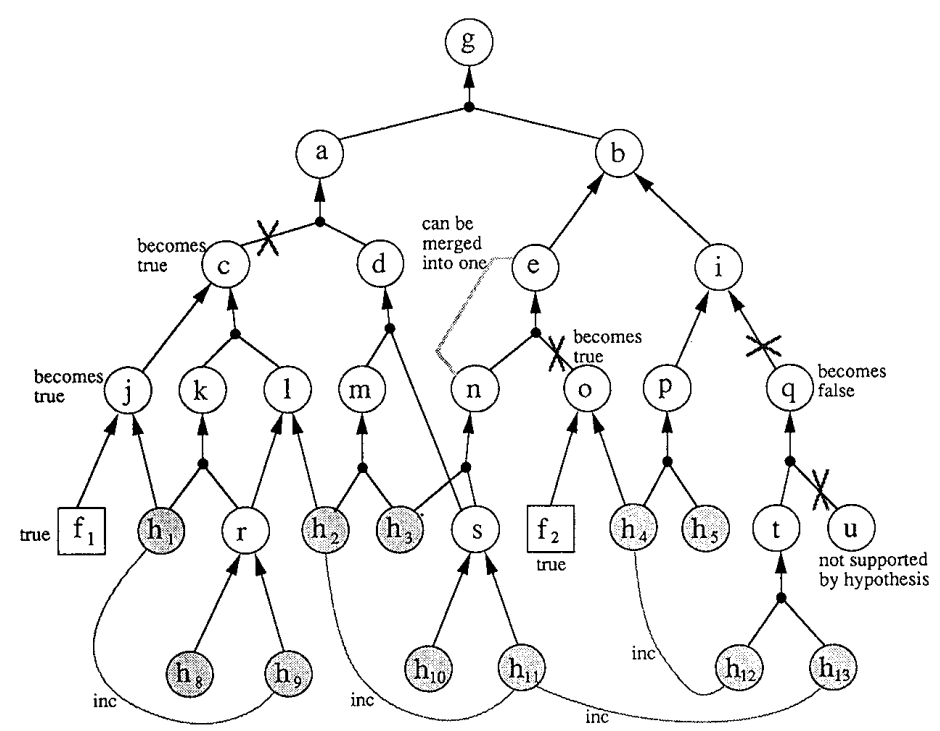

図 7 与えられたゴールに対する初期推論 パスネットワーク
索木中の解の位置に依存していずれのシステムで もより速く解を見い出せる場合があるが、図 9 は 探索の枝刈り効果をよく反映する全解探索の時間 で示している。

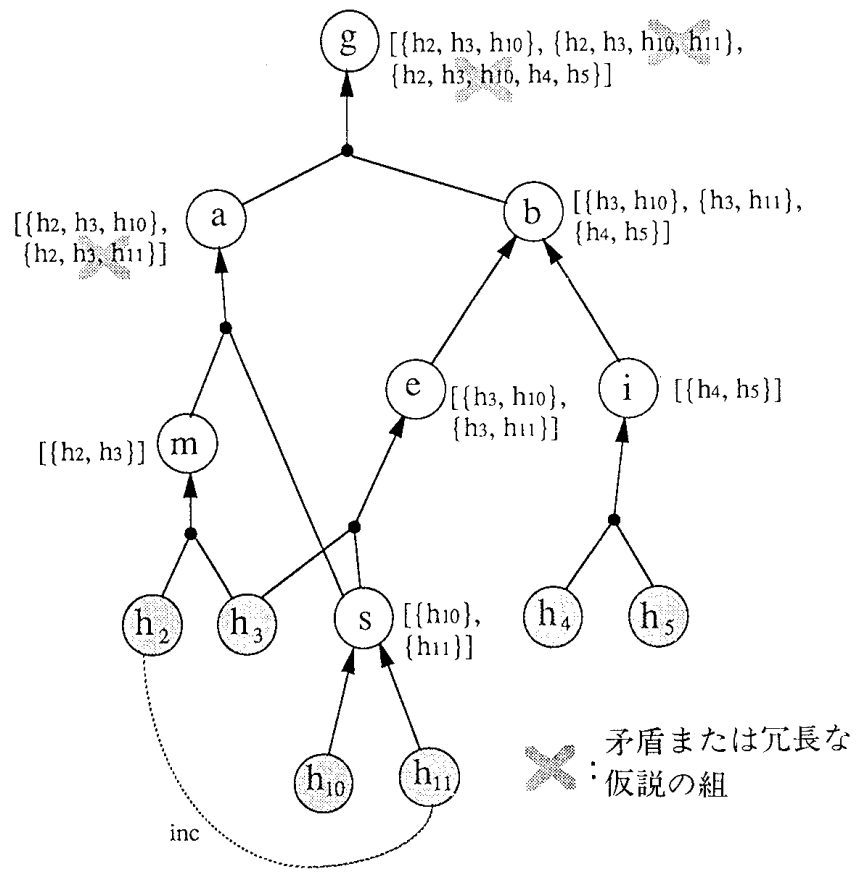

図 8 コンパイルされな推論パスネットワークと、 このネットワークに沿うボトムアップの仮説合成

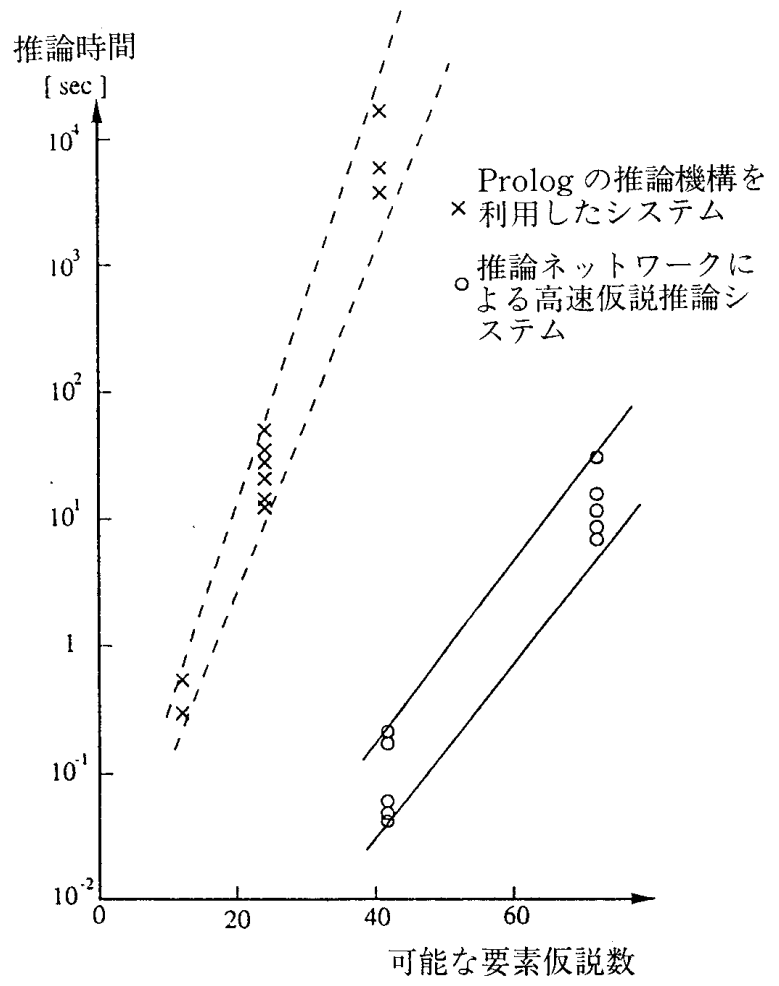

図 9 推論パスネットワークによる高速仮説 推論法による推論速度の向上 
この推論パスネットワークによる高速仮説推論 システムは大幅な高速化を達成しているが、図 9 でも縦軸が対数軸でとられているように、依然と して可能な要素仮説数に対して指数オーダの計算 時間となっている。先にも述べたように、通常の 意味での解の探索法の範囲に留まっていたのでは、 この指数オー多時間の壁は越えられない。この壁 を克服する方法として、過去に成功した類似の推 論結果を利用する “類推による高速仮説推論法 [13]”、推論の経験を以後の推論の高速化のために 知識として定着させる “経験に基づく学習による 仮説推論の高速化 ${ }^{[14]}$ ”、通常の推論がゴールが与. えられてから始まるのに対し、ゴールが与えられ る前に可能な推論はすべて行っておいてしまおう という考えによる “知識ベースのコンパイル ${ }^{[15] ”}$ などのアプローチが可能である。以下には、これ らとは異なるアプローチを紹介することにする。

\section{$(4-2)$ 整数計画法の近似解法の適用による多項 式時間の仮説推論法}

解仮説は一般に複数組得られるが、多くの場合、 ある評価基準のもとで最適な解仮説を求めること が必要になる。ここでは、要素仮説に重みを付し、 その重みの和を最小とする最適解仮説を求める仮 説推論を考えることにする。重みは例えば、故障 診断の場合にはシステム要素の故障の可能性の大 小、設計問題の場合はその部品を使用するとした ときのコストに対応して考えればよい。ここでは このような最適解計算の仮説推論に対して、01 整数計画法の近似解法により準最適解を多項式 オーダで求める方法の概要を紹介する ${ }^{[16]}$ 。

命題ホーン節論理表現と矛盾となる条件を陽に 示す制約による知識を対象とし、0-1 整数計画 法を適用するためにまず閉世界仮説(Closed World Assumption) と完備化 (completion)の考 え方を導入して知識を変換する。次いでアトムの 真／偽を真理值の $1 / 0$ 、そして同值記号 $(\Leftrightarrow)$ を 等号 $(=)$ で置き換える。そして

(1) $p=q_{1} \vee \cdots \vee q_{n}$

(2) $p=\left(q_{1} \wedge \cdots \wedge q_{n}\right) \vee r$
(ただし $\left.p_{j}, q_{j}, r \in\{0,1\}, j=1,2, \cdots, n\right)$

のような形のプール代数式を通常の 1 次不等式を 用いて等価的に表すのだが、この等価表現法は 1 通りではないが、例えば以下の表現法を採用でき る。

$$
\begin{gathered}
\frac{q_{1}+\cdots+q_{n}}{n} \leq p \leq q_{1}+\cdots+q_{n} \\
\frac{q_{1}+\cdots q_{n}+n r-(n-1)}{2 n} \leq p \leq \\
\frac{q_{1}+\cdots+q_{n}+n r}{n}
\end{gathered}
$$

全てのルール型知識はこれらの組合せ、あるいは 適宜必要な变数を補うことで表現可能である。

以上より、命題論理表現の仮説推論を $0-1$ 整 数計画法問題として定式化することができ、解仮 説に含まれる要素仮説の重みの和を目的関数に設 定することにより、これを最小化する $0-1$ 整数 解を求めることで最適解仮説が得られる。

しかし、知識ベース中のすべての知識を不等式 に変換して $0-1$ 整数計画法を適用するのは、現 われる变数の数が極めて大となり効率的でない。 そこで、与えられたゴールの証明に関与する知識 のみを、前節のコンパイル化推論パスネットワー クの形成と同様にして抽出、簡単化し、この範车 の知識だけを対象にして $0-1$ 整数計画法を適用 する。

掃き出し補数法 ${ }^{[17]}$ は $0-1$ 整数計画法の近似 解法であり、準最適解を効率的に求めることがで きる。打扔まかな手順を記すと、まず整数条件を はずして線形計画法の問題とし、これを効率的な シンプレックス法で解く。次いで、非整数度指数 を減らすような掃き出しを行いつつ、目的関数の 值を (最小化の場合) 漸减させ、適宜 $0 、 1$ への丸 めを行うことにより可能整数解を見い出す。続い て、見い出した可能整数解の周辺を局所探索する ことにより解の改善を行って、最適解に近い解を 見い出す。

図 10 は問題(知識ベース)の規模を表す要素仮 説数を横軸にして、求解の時間をプロットしたも のである。図 10 に同時に示されている全整数法と 
部分列挙法は $0-1$ 整数計画問題の厳密解法であ ク、0-1整数計画問題も NP 完全問題であるこ とより、これらをゴールに関する知識の簡単化後 に適用しても指数オーダの推論時間となっている。 近似解法である掃き出し補数法は非常に良い準最 適解を多項式オーダで求めることができ ${ }^{[17] 、 こ の ~}$ 性能が図 10 の結果にも現われている。AI 分野で は確率的に準最適解を求好手法として、シミュ レーティッド・アニーリング $(\mathrm{SA})$ や遺伝アルゴリ ズム $(\mathrm{GA})$ があるが、本手法はこれらとは異なる 一定の見通しをもった準最適解の高速探索法にな っている。仮説推論の実用的推論速度を達成する ため、本手法のような近似解法の導入は重要にな ると思われる。人間の知能もヒューリステイクな 知識の利用は別にすると、このようなメカニズム で現実的な対応を図っていると思える。

\section{5. ファジィ推論等との関連について}

筆者も以前にファジイ推論に関する研究を行っ

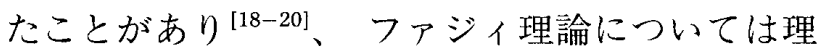

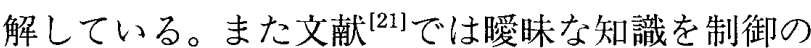
非決定性、多義性、不確実性、不完全性、ファジ イ性に分類して解説した。集合に関するファジィ 理論の扱いは他にはない独特なものであるが、事 柄の真理值を $0 \sim 1$ 間の数值で表す方法と仮説推 論等の不完全な知識の扱いとは幾分関係がある。 常に正しい完全な知識は真理值 1 、常に正しいと は限らない不完全な知識の真理值を 1 未満として 扱うことも考えられる。事実、そのようにして不 完全な知識が関与する非単調推論を扱った論文も あった ${ }^{[22,23]}$ 。また、本稿で設計問題への適用と整数 計画法を適用して最適解仮説を求める仮説推論に 関連して紹介したように、仮説推論でも本稿では 重みと称した数值的な測度が導入されている。こ れらは求めた解の良さを示したり、尤らしいとこ ろから優先して推論することで推論を効率化する という点で、重要な役割を果たしている。

では、仮説推論とファジィ推論の差異はどこに あるのだろうか? 基本的な差異は、仮説推論は無

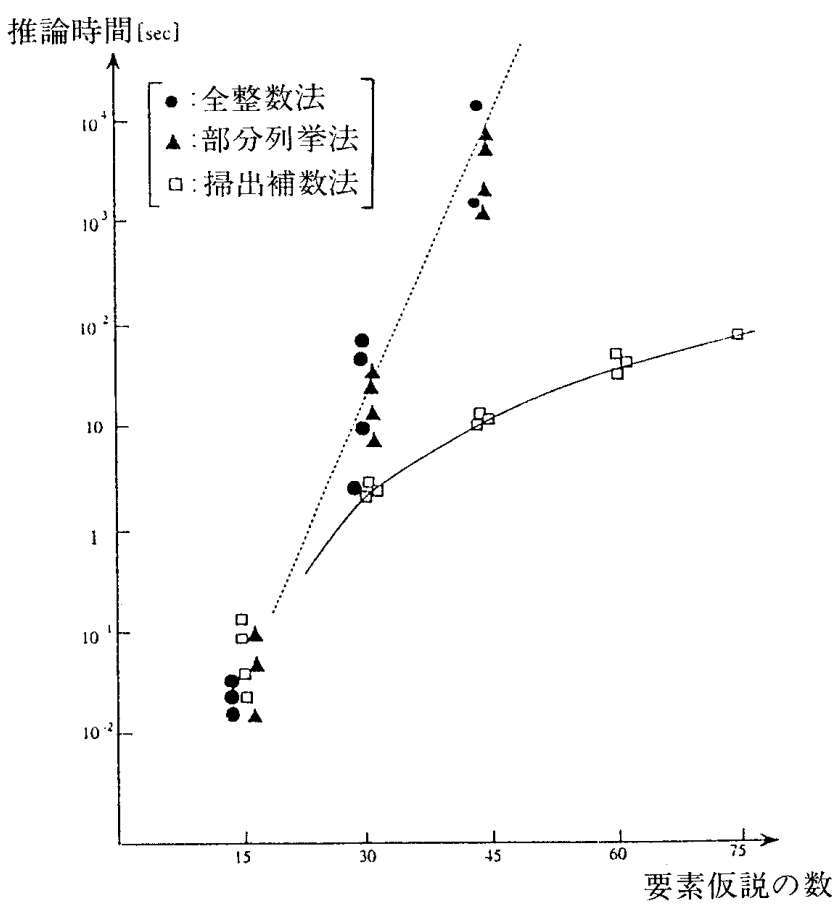

図10 $0-1$ 整数計画法を適用した仮説推論 システムの推論時間

矛盾性という制約を満なす解を求める(発想的推 論)メカニズムになっているのに対し、(現状の) フ アジィ推論は結論の真理值を算出する(演繹推論) メカニズムである点であろう。ファジィ推論であ る事柄が真理值 0.98 で結論として得られたと しても、本当に正しいか(真理值が 1 か)どうかを 確証できない。真理值 1 と真理值 0.99 との間には 意味的に大きなギャップがあることになる。仮説 推論で得られる解は、与えられた制約(ゴールの証 明を可能にすることと無矛盾性)を満たしている ことが保証されている。そこでの数值的な測度は、 その絶対值が意味をもつというよりは、推論の効 率化を困る役割の方が大きいと言える ${ }^{[24]}$

最近話題になっている論理プログラミングの帰 納的学習法である逆導出 ${ }^{[25]}$ は、仮説推論の発想よ りも一段と広い範囲の知識 (仮説)を生成するメ力 ニズムとなっており、今後、仮説推論のメカニズ ムの研究とのインタラクションは興味深い領域と なろう。

最後に必ずしも実用的ではないが、確率を導入 した論理 ${ }^{[26]}$ と仮説推論 ${ }^{[27]}$ の理論的研究があるの で、参考になるかと思い付言しておく。 


\section{参 考 文 献}

[1]石塚 満：不完全な知識の操作による次世代知 識ベース・システムへのアプローチ、人丁知能学 会誌、Vol.3，No.5, pp.552-562(1988)

[2]石塚 満：次世代エキスパートシステムへ向け て、「エキスパートシステム(石塚、小林(編著))」 丸善の第 7 章 (1991)

[ 3 ] D. Poole, R. Aleliunas, R. Goebel : A Logical Reasoning System for Defaults and Diagnosis, in the Knowledge Frontier: Essays in the Knowledge Representation(N. J. Cercone and G. McCalla (eds.)), Springer-Verlag, N.Y. (1987)

[4] D. Poole : A Logical Framework for Default Reasoning, Artif. Intelli., Vol.36, pp.2747 (1988)

[ 5] 國藤 進：仮説推論、人工知能学会誌、Vol.3, No.1, pp.94-102(1988)

[6] 松田、石塚：仮説推論システムの拡張知識表現 と概念学習機構、人工知能学会誌、Vol.3, No.1, pp.94-102 (1988)

[7] M. Ishizuka, T. Matsuda : Knowledge Acquisition Mechanisms for a Logical Knowledge Base including Hypotheses, Knowledge-Based Systems, Vol.3, No.2, pp.77-86(1990)

[8] 牧野、石塚：制約評価機構付き仮説推論システ ムとその回路ブロック設計への応用、人工知能学 会誌、Vol.5, No.5,pp.640-648(1990)

[9] H. Kautz and B. Selman : Hard Problems for Simple Default Logics, Proc. 1st Int'l Conf. on Principles of Knowledge Representation and Reasoning (KR'89) (1989)

[10] T. Bylander, d. Allemang, et.al. : Some Results Concerning the Complexity of Abduction, ibid.

[11] J. deKleer: An Assumption-based TMS, Artif. Intelli., Vol.28, pp.127-162(1986)

[12] 伊藤、石塚：推論パスネットワークによる高速 仮説推論システム、人工知能学会誌、Vol.6, No. 4, pp.501-509(1991)

[13］阿部、石塚：推論パスネットワーク上での類推 による高速仮説推論システム、人工知能学会誌、 Vol.7, No.1, pp.77-86(1992)
[14] 牧野、石塚：経験に基づく学習機能を備えた仮 説推論システム、知識のリフォメーション・シン ポジウム論文集、情報処理学会、pp.109118 (1991)

[15] 鶴田、石塚：発想的知識生成のための命題論理 知識ベースのコンパイル法、人工知能学会誌、 Vol.6, No.1, pp.117-123(1991)

[16] 岡本、石塚：0-1整数計画法を用いて最適解 を得る仮説推論法、情処人工知能研資料、AI-817 (1992.3)

[17] E. Balas, C. Martin : Pivot and Complement -- A Heuristic for 0-1 Programming, Management Science, Vol.26, pp.86-96(1980)

[18] M. Ishizuka, K. S. Fu, J. T. P. Yao : Inference Procedures under Uncertainty for the ProblemReduction Method, Information Science, Vol. 26, pp.179-206(1982)

[19] M. Ishizuka : Inference Methods based on Extended Dempster \& Shafer's Theory for Problems with Uncertainty/Fuzziness, New Generation Computing, Vol.1, No.2, pp.159168(1983)

[20]金井、石塚：Prolog-ELF：ファジイ論理を組み 込んだProlog、情処論文誌、Vol.27, No.4, pp. 411-416(1986)

[21]石塚：曖昧な知識の表現と利用、情報処理、Vol. 26, No.12, pp.1481-1486(1985)

[22] E. Rich : Default Reasoning as Likelihood Reasoning, AAAI-83(1983)

[23] M. L. Ginsberg : Non-monotonic Reasoning using Dempster's Rule, AAAI-84 (1984)

[24] 石塚：仮説推論等の組合せ問題の高速推論につ いて最近考えること、情処人工知能研資料、AI- 83 -1-14(1992.7)

[25] S. Muggleton, W. Buntine : Machine Invention of First Order Predicates by Inverting Resolution, 5th Int'l Conf. on Machine Learning, pp.339-352 (1988)

[26] N. J. Nilsson: Probabilistic Logic, Artif. Intelli., Vol.28, pp.71-87(1986)

[27] D. Poole : Logic Programming, Abduction and Probability, FGCS'92, Tokyo(1992)

（1992年 6 月 25日 受付） 
[問い合わせ先

干106 東京都港区六本木7-22-1

東京大学 生産技術研究所

石塚 満

땐ㄷㄴ 03-3402-6231 (内) 2651

[AX : 03-3402-5078

\section{著者 紹 介}

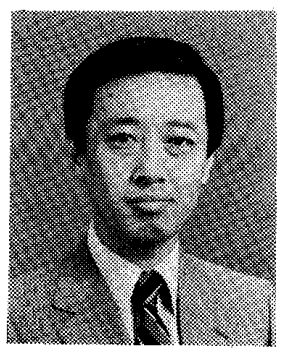

石塚 満(いしづかみつる)

東京大学 生産技術研究所

1971年 東大電子工学科卒. 1976年

同大学院博士課程修了, 工学博士. 同

年 NTT 入社, 横須賀研究所勤務.

1978年 東大生産研究所助教授, 1992

年 同教授，現在に至る. 1980年より

1 年半の間, 米国パデュー大学客員

準教授. 現在, 人工知能学会理事, 情 報処理学会人工知能研究会主查.

人工知能, 知識システム, ビジュア ルコンピューティング, 並列コンピ ューティングの研究に従事している. 